\title{
ACRL Officers and Committee Chairmen
}

Note: Terms of office are listed after names-if annual appointments, no terms listed.

\section{EXECUTIVE COMMITTEE}

Chairman and President: Philip J. McNiff, Director, Boston Public Library, Boston, Mass. 02117 (1968-71); President-elect: Anne C. Edmonds, Librarian, Mt. Holyoke College, South Hadley, Mass. 01075 (1969-72); PastPresident: David Kaser, Director of Libraries, Cornell University Libraries, Ithaca, N.Y. 14850 (1967-70); J. Donald Thomas, ACRL Executive Secretary, 50 E. Huron St., Chicago, Ill. 60611 (ex-officio).

\section{BOARD OF DIRECTORS}

\section{ACRL OFFICERS}

President: Philip J. McNiff, Director, Boston Public Library, Boston, Mass. 02117; VicePresident and President-Elect: Anne C. Edmonds, Librarian, Mt. Holyoke College, South Hadley, Mass. 01075; Past President: David Kaser, Director of Libraries, Cornell University, Ithaca, N.Y. 14850; Executive Secretary: J. Donald Thomas, 50 East Huron Street, Chicago, Ill. 60611.

\section{DIRECTORS-AT-LARGE}

Herbert Cahoon, Director of Library Services, The Pierpont Morgan Library, 33 East 36th Street, New York, N.Y. 10016 (1969-73); Mark M. Gormley, Director of Libraries, University of Wisconsin, 2311 East Hartford Avenue, Milwaukee, Wis. 53211 (196973); Norman E. Tanis, Director of Libraries, San Fernando Valley State College, Northridge, Calif. 18111 (1968-72); David C. Weber, Associate Director, Stanford University Libraries, Stanford, Calif. 94305 (196872).

Directors on ALA Council (ex-officio members without vote)

Robert H. Blackburn, Chief Librarian, University of Toronto, Toronto 5, Ontario, Can. (1967-71); Andrew J. Eaton, Director of Libraries, Washington University, St. Louis, Mo. 63130 (1967-71); Andrew Horn, Dean, School of Library Science, University of California at Los Angeles, 401 Hilgard Avenue, Los Angeles, Calif. 90024 (1968-72); James F. Holly, Librarian, Macalester College, Grand and Macalester Streets, St. Paul, Minn. 55101 (1969-73); Robert K. Johnson, University Librarian, The University of Arizona, Tucson, Ariz. 85721 (1969-73); Sarah D. Jones, Librarian, Goucher College, Towson, Baltimore, Md. 21204 (1967-71);
James O. Wallace, Librarian, San Antonio College, 1001 Howard Street, San Antonio, Tex. 78212 (1967-71).

\section{ACRL COMMITTEE CHAIRMEN}

Unless otherwise stated, person listed is Chairman.

Committee on Appointments (1969) and Nominations (1970): Barbara LaMont, Librarian, Vassar College, Poughkeepsie, N.Y. 12601 (1968-70).

Committee on Appointments (1970) and Nominations (1971): David C. Weber, Associate Director Libraries, Stanford University, Stanford, Calif. 94305.

Audio-Visual Committee: Herman L. Totten, Librarian, Wiley College, Marshall, Tex. 75670 (1969-71).

Committee on Community Use of Academic Libraries: Richard Quick, Director of Libraries, State University of N.Y. at Geneseo, Geneseo, N.Y. 14454 (1964-70).

Advisory Committee on Cooperation with Educational and Professional Organizations: James F. Govan, Librarian, Swarthmore College, Swarthmore, Pa. 19081 ( 1966-70).

Committee on Grants: H. Vail Deale, Director of Libraries, Beloit College, 620 College St., Beloit, Wisc. 53512 (1966-70).

Committee on Legislation: Robert A Golter, Librarian, Wheaton College, Wheaton, Ill. 60187 (1969-71).

Committee on Library Services: Mrs. Elizabeth W. Swint, Head, Circulation Department, Joint University Libraries, Nashville, Tenn. 37203 (1969-71).

Committee on Library Surveys: Edwin E. Williams, Associate University Librarian, Harvard University, Cambridge, Mass. 02138 (1965-70).

Local Arrangements Committee: Howard A. Sullivan, Assistant Director for Technical Services, Wayne State University, Detroit, Mich. 48202.

Planning and Action Committee: Anne C. Edmonds, Librarian, Mt. Holyoke College, South Hadley, Mass. 01705 (1969-72).

Committee on Standards and Accreditation: Norman E. Tanis, San Fernando Valley State College Library, Nordhoff Street, North Ridge, Calif. 91324 (1963-71).

Ad Hoc Subcommittee on the Revision of the Junior College Library Standards (indefinite appointments): James O. Wallace, Director of Library Services, San Antonio College, 1001 Howard Street, San Antonio, Tex. 78212 (1966- ). 


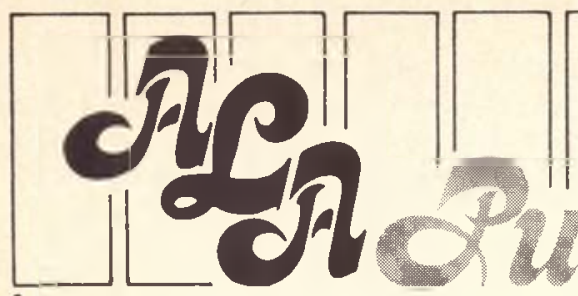

Historical Sets,

Collected Editions, and

Monuments of Music

A Guide to Their Contents, $2 \mathrm{~d}$ ed.

Anna Harriet Heyer, Compiler

A unique and comprehensive bibliography of published music. It records and indexes the major sets of music, including the definitive editions of the works of individual composers, and most of the major collections of music. Entries, using the Library of Congress form, give composer or compiler, title of the collection, place of publication, publisher, date, collation, and contents of the collection. More than one-third of the entries are new; entries retained from the previous edition are revised, expanded and updated. Indexed by composer, title, and form or medium. Cloth

$\$ 25.00$

\section{Guide to}

\section{Japanese Reference Books}

Nihon no Sankotosho

Edited and Translated by the International House Library

The Japanese counterpart to Winchell's Guide to Reference Books. Includes books and periodicals. Annotated. Entries arranged by subject in romanized Japanese, Japanese orthography and English translation of the title. Cloth

$\$ 10.00$

\section{Subject Guide to Major} U.S. Government Publications Ellen Jackson

This comprehensive, selective subject guide covers titles of permanent importance from the earliest period to early 1967. Only publications issued by the Government Printing Office and usually available in regional depository libraries are included. Entries are arranged by subject under Library of Congress headings and give title, author, date, pages, agency of issue, and document number. Published posthumously. Cloth

\section{American Library Laws}

3d ed., 3d Supplement 1967-1968

Alex Ladenson, Editor

Arrangement is by type of library or subject with separate listings for each state and territory. Detailed index. Cloth $\$ 6.50$

Bibliography of Place-Name Literature

United States and Canada, 2d ed.

Richard B. Sealock and Pauline A. Seely, Compilers

The authors' standard guide to literature dealing with place names in the United States and Canada in a new edition, revised and enlarged. Separate author and subject indexes. Cloth

$\$ 7.50$

Biographical Directory of Librarians in the Field of Slavic and East European Studies

Peter A. Coy, Compiler and Editor

Laurence H. Miller, Editorial Assistant

This directory lists biographies of more than 300 librarians, information specialists, archivists, bibliographers, and editors with subject or language competence in the Slavic or East European fields.

Paper

$\$ 3.25$

Reference Books for

Small and Medium-sized

Public Libraries

Committee of the Reference

Services Division, ALA

An annotated buying list of the 634 most convenient, useful, and productive adult reference works for small and mediumsized public libraries. List supplies bibliographic information and comparative evaluation; descriptive, critical annotations. Directory of publishers and author, subject, title, index. Paper

$\$ 4.50$ 
Ad Hoc Committee for the Revision of the ALA Standards for College Libraries: Stanley McElderry, Dean, Graduate School of Library Science, University of Texas, Austin, Tex. 78712 (1968-69).

AAJC-ALA (ACRL) Committee on Junior College Libraries: Edmon Low, Professor of Library Science, Department of Library Science, University of Michigan, Ann Arbor, Mich. 48104 (1968-70).

AAC-ACRL Committee on College Libraries: Dr. Richard L. Barber, Dean of College of Arts and Sciences, University of Louisville, Louisville, Ky. 40208.

AASL-ACRL Committee on Instruction and Use of Libraries: James F. Govan, Librarian, Swarthmore College Library, Swarthmore, Pa. 19081 ( 1968-70).

ACRL-ARL Joint Committee on University Library Standards: Robert B. Downs, Dean of Library Administration, University of Illinois, Urbana, Ill. 61803.

Publications Commiltee: Robert T. Grazier, Associate Director of Libraries, Wayne State University, 5210 Second Street, Detroit, Mich. 48202 (1966-69).

Choice: Editor, Peter M. Doiron, 100 Riverview Center, Middletown, Conn. 06457 (1964- ); Editorial Board Chairman, Joseph H. Treyz, Assistant Director, University of Michigan Library, Ann Arbor, Mich. 48104 (1967-70); Advertising and Promotion Manager, Clifford R. Fulton, 100 Riverview Center, Middletown, Conn. 06457 (1967- ).

College \& Research Libraries: Editor, Richard M. Dougherty, Associate Director of Libraries, Norlin Library, Room 105, University of Colorado, Boulder, Colo. 80302; Associate Editor, William H. Webb, Assistant Librarian, University of Colorado Libraries, Boulder, Colo. 80302; News Editor, Michael Herbison, Assistant Librarian, Casper Community College, Casper, Wyoming.

ACRL Monograph Series: Editor, Edward G. Holley, Director of Libraries, University of Houston, 3801 Cullen Blvd., Houston, Tex. 77004 (1969-).

ACRL Microform Series: Editor, Felix Reichmann, Assistant Director of Libraries, Cornell University, Ithaca, N.Y. 14850.

ACRL Representative to the American Association for the Advancement of Science: Theodore C. Hines, Associate Professor, School of Library Service, Columbia University, Butler, New York, N.Y. 10022 (December 1966-71).

ACRL Representative to the American Council on Education: Robert B. Downs, Dean of Library Administration, University of Illinois, Urbana, Ill. 61803 (1964-70).

ACRL Representative to the ALA Membership Committee: Frances Kennedy, Librarian, Oklahoma City University, Oklahoma City, Okla. 73106 (1967-71).

\section{SECTION AND SUBSECTION OFFICERS}

College Libraries Section

Chairman: John E. Scott, Librarian, West Virginia State College, Institute, W.Va. 25112; Vice-Chairman and Chairman-elect: Carl $\mathrm{H}$. Sachtleben, Director of Libraries, Valparaiso University, Valparaiso, Ind. 46383.

\section{Junior College Libraries Section}

Chairman: Ruthe Erickson, Assistant Coordinator of Instructional Resources, Junior College District of St. Louis, St. Louis County, 7508 Forsyth, St. Louis, Mo. 63105; Vice-Chairman and Chairman-elect: Mrs. Joleen Bock, Director of Library Service, College of the Canyons Library, Santa Clarita Valley Junior College District, 24609 Arch St., Newhall, Calif. 91321.

\section{Rare Book Section}

Chairman: Robert J. Adelsperger, Special Collections, Librarian, University of Illinois at Chicago Circle Campus, P.O. Box 8198, Chicago, Ill. 60680; Vice-Chairman and Chairman-elect: Julius P. Barclay, Chief, Division of Special Collections, The Stanford University Libraries, Stanford, Calif. 94305.

\section{Subject Specialist Section}

Chairman: Marcia J. Miller, Chief, Division of Cataloging and Acquisitions, United States Department of Labor, Washington, D.C. 20210; Vice-Chairman and Chairman-elect: Eleanor Buist, Research Associate, Columbia University, 90 LaSalle St., New York, N.Y. 10027. Agricultural aND Biological SCIENCES Subsection. Chairman: Howard Rovelstad, Director of Libraries, University of Maryland, College Park, Md. 20740; ViceChairman and Chairman-elect: Joseph C. Shipman, Director, Linda Hall Library, Science and Technology, 5109 Cherry St., Kansas City, Mo. 64110. Art Subsection. Chairman: Wolfgang M. Freitag, Lecturer on the Fine Arts and Librarian of the Fine Arts Library, Fogg Art Museum, Harvard University, Cambridge, Mass. 02138; Vice-Chairman and Chairman-elect: Peter Anthony, Architecture and Fine Arts Librarian, University of Manitoba, Winnipeg 19, Manitoba. Educational and Behavioral Science Subsection. Chairman: Donald Leatherman, Librarian, Education Library, University of Michigan, Ann Arbor, Mich. 48104; ViceChairman and Chairman-elect: Dr. Sidney Forman, Librarian, Teachers College, Columbia University, New York, N.Y. 10027. LAw and Political Science Subsection. Chairman: Roy M. Mersky, Librarian, and Director of Research, University of Texas School of Law, 2500 Red River, Austin, Tex. 78705; Vice-Chairman and Chairman-elect: Iris J. 
Wildman, Acquisitions Librarian, Yale Law Library, 127 Wall St., New Haven, Conn. 06520. Slavic and East European SubsecTION. Chairman: Joseph Placek, Head Slavic Section, Technical Services, University of Michigan Library, Ann Arbor, Mich. 48104; Vice-Chairman and Chairman-elect: Dr. Ivan L. Kaldor, Professor of Library Science, School of Library Science, State University
College of Arts and Science, Geneseo, N.Y. 14454 .

University Libranies Section

Chairman: Roscoe Rouse, University Librarian, Oklahoma State University, Stillwater, Okla. 74075; Vice-Chairman and Chairman-elect: David W. Heron, Director, University of Kansas Libraries, Lawrence, Kan. 66044.

\section{From Inside the DLP}

\section{By Dr. Katharine M. Stokes}

College and University Library Specialist, Library Planning and Development Branch, Division of Library Programs, Bureau of Adult, Vocational, and Library Programs, U.S. Office of Education, Washington, D.C. 20202.

Several small North Carolina college libraries are being assisted by grants under Title III of the Higher Education Act for Strengthening Developing Institutions. In 1968, Pembroke State College (originally devoted to the education of Indians, but integrated with the admission of white students in 1953) and Wilmington College applied for a grant to permit reclassification of their collections. Salaries were awarded to employ a library specialist to coordinate the project, and two library assistants for Pembroke and one for Wilmington. After a year's operation the cooperative program was considered "an unqualified success." In 1969, Wayne Community College in Goldsboro, Mount Olive Junior College, and Pembroke State College received a Title III Grant. The previous year's experience resulted in Pembroke State College "providing many technical services" to Wayne and Mount Olive in the reclassification of their collections. Mrs. Mildred Councill, the librarian of Wayne, says that she saw how her neighbors at Pembroke and Wilmington were benefiting and decided to try for a grant for her library. The Title III benefits have thus been spread a little further, from two libraries to four.

In the Library Journal for May 1, 1969, the Piedmont Library Center, comprising twenty member libraries, was described by Herbert Poole. Three of these libraries are in Bennett, Greensboro, and Guilford Colleges, all situated in Greensboro, which are being assisted by a Title III Grant. Mr. Poole, director of libraries at Guilford, is also coordinator for the library phase of the Title III program of the three colleges, whose administrators expect to "temper the rising costs of instruction by sharing library resources." Plans are underway to consolidate operations, both technically and in areas of collection strength, which will result in less overlap in the three libraries and release funds for further strengthening of the library holdings. Centralized processing, personnel exchanges, and open access to faculty and students, with a uniform ID card and circulation system, are parts of their plans.

If you think your college could qualify as a developing institution, you may want to discuss the Title III library possibilities with your campus administrators. Applications for awards have been processed in the late fall during the last two years and grants were announced in the early spring. James M. Holley, Division of College Support, is the administrator for the program. His address is 7 th \& D Streets, S.W., GSA Building, Room 4719, Washington, D.C. 20202.

LATE Information: Payments on Title II-A (Higher Education Act) awards will be made on a scheduled basis this year instead of on a lump sum basis as in previous years, but you can be sure you'll get the whole amount before June $30,1970$.

\section{REVISE SLAVIC LIBRARIANS DIRECTORY}

The Slavic and East European Subsection of the Association of College and Research Libraries (American Library Association) is preparing a revised edition of its Directory of Librarians in the Field of Slavic and Central European Studies. The Directory, first published in 1967, includes librarians, archivists, bibliographers, and information specialists with a wide range of academic and professional training and experience, from beginning professional librarians to senior personnel in the field. Persons eligible for inclusion are library school graduates or students, and/or those employed in a professional position, or those performing libraryrelated work involving Slavic or Central European languages. (Coverage is limited to the USA and Canada.)

For further information write Peter A. Goy, Editor, Directory of Slavic and Central European Librarians, c/o City College Library, Rm. 312, New York 10031. 